\title{
Pedagogical conditions for forming the information competence of pedagogical students
}

\author{
A.R. Kamaleeva ${ }^{1 *}, O . Y u$. Muller ${ }^{2}$, and E.V. Mityushchenko ${ }^{3}$ \\ ${ }^{1}$ FSBSI "Institute of Pedagogy, Psychology and Social Problems", Kazan, Russia \\ ${ }^{2}$ Surgut State University, Surgut, Russia \\ ${ }^{3}$ Surgut State Pedagogical University, Surgut, Russia
}

\begin{abstract}
The article is devoted to the problem of the formation of information competence of students of the pedagogical direction. An approach to the essence of the concept, structure and content of information competence is stated. The pedagogical conditions for the formation of information competence of future teachers are presented, and the results of experimental work on the introduction of pedagogical conditions into the educational process, aimed at the formation of information competence of students of the pedagogical direction.
\end{abstract}

\section{A problem statement}

In the preparation of future subject teachers, an essential role is played by the formation of information competence. Its role is recorded, including in the professional standard of the teacher - in the formulation of labor actions, the necessary skills [1, 2].

Trends in the development of science, technology and society as a whole require a high level of information competence formation. At the same time, attention must be paid not only to the confident use of modern information technologies, but also to the mastery by students of pedagogical directions of various methods of information processing $[3,4,5,6]$.

Within the framework of this study, the information competence of students of the pedagogical direction is understood as the integrative and functional quality of the individual, consisting in the ability to effectively search and process information, master the means of implementing information processes, analyze and evaluate information resources and the nature of their use in the process of solving educational, project, methodical, pedagogical activity [7]. In the process of work, the pedagogical conditions for the formation of information competence were determined in the course of professional training of future teachers.

\footnotetext{
*Corresponding author: ipcs-profped@yandex.ru
} 


\subsection{The objective of the work}

The search for effective ways to form the information competence of future teachers today is actively pursued in theoretical and empirical research $[8,9]$. There is an acute question about the structure of information competence, about the diagnosis of the level of its formation $[10,11,12,13]$.

In this study, the structure of the information competence of students of the pedagogical direction is determined, taking into account the specifics of future professional activities.

The structure of the information competence of a student of the pedagogical direction includes [14]:

- epistemological component - characterizes the knowledge component of information competence and includes all the elements of knowledge necessary and sufficient for orientation in the modern information space;

- praxeological component - outlines a list of skills necessary for successful, effective information activities for knowledge or communication, for orientation in the modern information space;

- axiological component - determines the motivational and value component of information competence: these are values and value orientations, motives of information activity, a critical attitude to the perception and adequate assessment of the truth of information, readiness for self-education, awareness of its need.

Within the framework of the experiment to test the effectiveness of pedagogical conditions, aimed at the formation of information competence of students of the pedagogical direction, the diagnostics of the formation of information competence of students was carried out. As tools for measuring the levels of individual components of information competence, the following were used: questioning, testing, the method of studying the value orientations of $\mathrm{M}$. Rokich, the method of studying the motives of the educational activity of students of pedagogical specialties (adapted by M.M. Kalashnikova, V.N. Kosyrev, O.V. Schekochikhin [15]), a technique for diagnosing educational motivation of students (A.A. Rean and V.A. Yakunin, modified by N.Ts. Badmaeva [16]); situational tasks and tasks aimed at testing the skills necessary for successful, effective information processing using various means and mastering information technologies to solve the problems of current educational and future professional and pedagogical activities. Statistical methods of processing the research data were applied to the measurement results.

\section{Materials and the results of the research}

In the modern practice of training future teachers in the context of the formation of their information competence, there are a number of contradictions (at different levels of knowledge) [14], which made it possible to determine the research problem: what should be the pedagogical conditions for the formation of information competence of a student in a pedagogical direction?.

The purpose of this study is to substantiate and test the pedagogical conditions for the formation of information competence of students in the pedagogical direction. This goal determined the research objectives, the implementation of which is highlighted in this article: to determine, theoretically substantiate and experimentally test the effectiveness of pedagogical conditions aimed at the formation of information competence of students of a pedagogical direction; to develop and introduce into the educational process an information educational environment for the formation of information competence of students of a pedagogical direction. 
The following were identified as pedagogical conditions for the formation of information competence of future teachers: the widespread introduction into the educational process of technologies for enhancing cognitive activity, based on the visualization of educational material (reference maps, diagrams and notes, clusters, mental maps, etc.) [17, 18]; creation and introduction into the educational process of an environment that develops the information competence of students of the pedagogical direction; integration of the pedagogical capabilities of the studied disciplines; building an individual educational route for each student based on monitoring his educational achievements.

Let us dwell separately on the condition (online course), which at the same time acts as an environment for the implementation of other conditions in whole or in part.

Information competence manifests itself in information activity, therefore, one of the pedagogical conditions for its formation is the creation and implementation in the educational process of a specific information educational environment based on the educational portal: the online course "Information Technologies in Professional Activity" [19], which also acts as an information, software and technological base for the implementation of other conditions.

The main professional educational programs based on research in pedagogical areas of training contain such a discipline.

It should be noted the pronounced professionally and practice-oriented nature of the discipline, which makes it possible to vividly implement the integration of disciplines as a pedagogical condition for the formation of a student's information competence, which contributes to the intensification, systematization, optimization of educational and cognitive activities, the development of students' creative thinking and their immersion in quasiprofessional activities, allowing see the prospect of using specific knowledge, skills, methods of action in future professional activities.

The formation of students' methods of information processing with the help of various information models, the development of software tools for their construction is provided by such a pedagogical condition as the use in the educational process of technologies for activating cognitive activity based on the visualization of educational material [20,21].

The online course, as a specific information educational environment, also makes it possible to monitor the student's educational achievements and build on its basis an individual educational route for mastering the discipline as a personal way of realizing the student's potential in education through the implementation of the algorithm for forming the student's individual educational route.

Figure 1 shows the mechanism for creating pedagogical conditions for the formation of information competence of students in the pedagogical direction.

We have defined an online course in the discipline "Information technology in professional activity" (hereinafter "IT in professional activity") as a platform for the implementation of pedagogical conditions for the formation of information competence of students in pedagogical areas. The online course is developed and operates on the basis of the MOODLE educational platform, which allows you to create a personalized learning environment (posted on the domain of the educational portal at http://els.surgpu.ru). The platform allows you to automate the formation of an individual educational route based on monitoring the educational achievements of students. 
Pedagogical conditions:

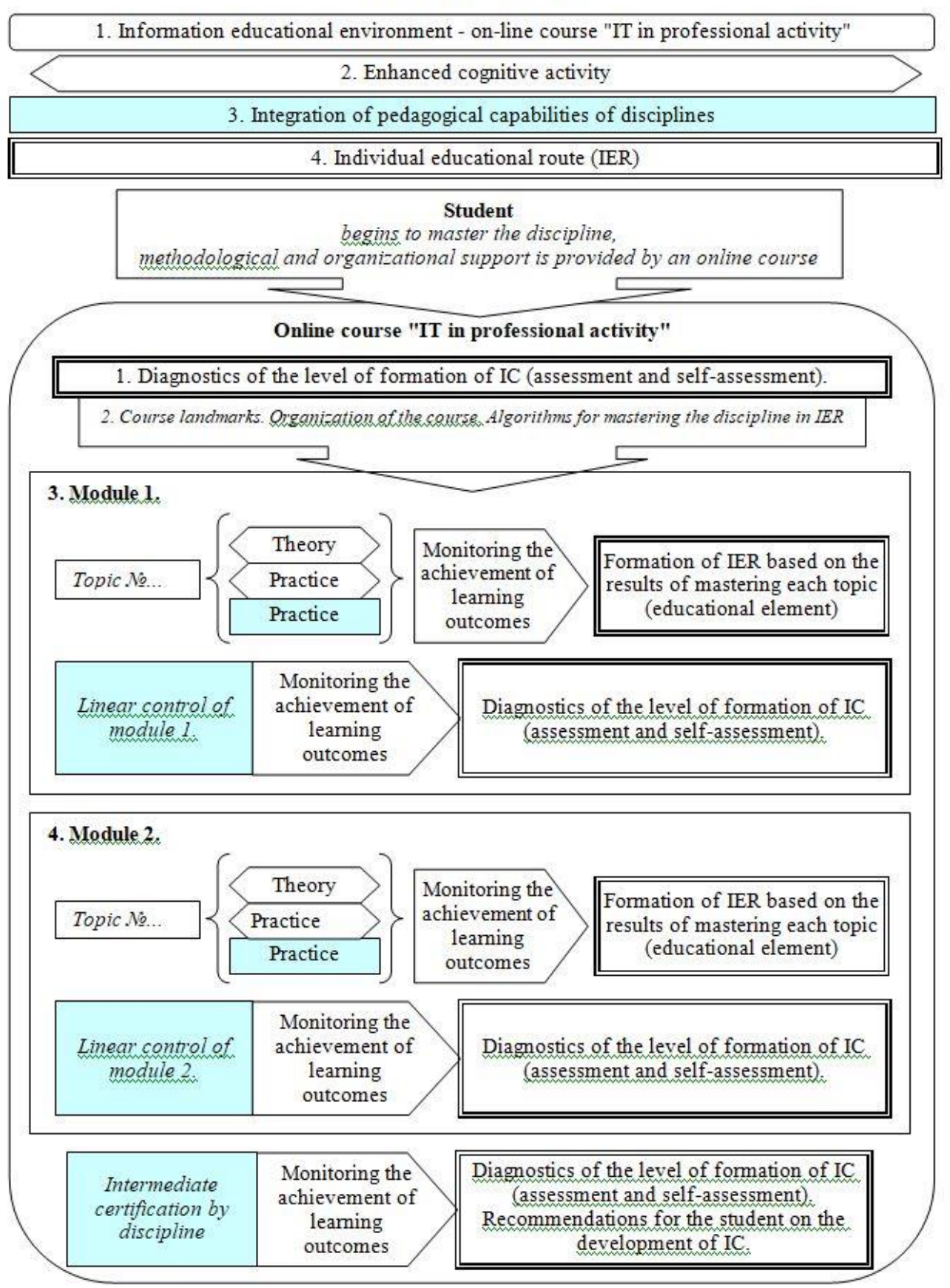

Fig. 1. The mechanism of creating pedagogical conditions for the formation of information competence (IC) of students of the pedagogical direction. 
Table 1. Projection of the structure of information competence on the discipline "IT in professional activity".

\begin{tabular}{|c|c|c|c|c|}
\hline \multirow{2}{*}{$\begin{array}{l}\text { Discipline } \\
\text { module }\end{array}$} & \multirow{2}{*}{$\begin{array}{l}\text { The purpose } \\
\text { of mastering } \\
\text { the module }\end{array}$} & \multicolumn{3}{|c|}{ Components of information competence } \\
\hline & & Motivational & Epistemological & Praxeological \\
\hline 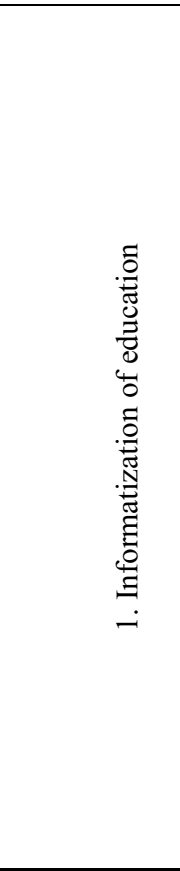 & $\begin{array}{l}\text { Formation of a } \\
\text { system of } \\
\text { concepts about } \\
\text { the essential } \\
\text { characteristics } \\
\text { of the use of } \\
\text { information } \\
\text { technologies in } \\
\text { education }\end{array}$ & $\begin{array}{l}\text { understanding the } \\
\text { value and } \\
\text { meaning, } \\
\text { including } \\
\text { personal, the } \\
\text { consequences of } \\
\text { informatization of } \\
\text { society; } \\
\text { - a high level of } \\
\text { development of } \\
\text { motivation to use } \\
\text { various means of } \\
\text { information } \\
\text { processing to } \\
\text { solve problems of } \\
\text { current } \\
\text { educational and } \\
\text { future professional } \\
\text { and pedagogical } \\
\text { activities; }\end{array}$ & $\begin{array}{l}\text { - a critical attitude to the } \\
\text { perception and adequate } \\
\text { assessment of the truth of } \\
\text { information, } \\
\text { understanding of the } \\
\text { problems of authorship } \\
\text { and copyright in the light } \\
\text { of the active development } \\
\text { of information and } \\
\text { communication } \\
\text { technologies; } \\
\text { - the student's } \\
\text { understanding of the } \\
\text { breadth and volume of the } \\
\text { information field } \\
\text { available with the help of } \\
\text { modern information } \\
\text { technologies; of the } \\
\text { - knowledge of tor } \\
\text { principles of work and } \\
\text { methods of effective } \\
\text { study of modern software } \\
\text { tools for information } \\
\text { technology; }\end{array}$ & $\begin{array}{l}\text { - the ability to } \\
\text { master new } \\
\text { information } \\
\text { technology; }\end{array}$ \\
\hline 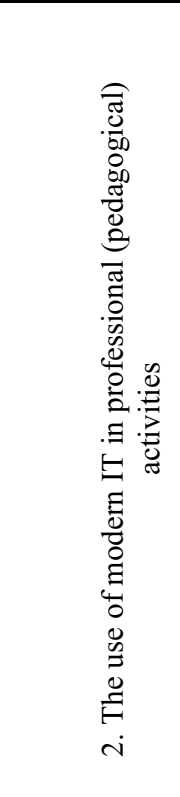 & $\begin{array}{l}\text { Formation of } \\
\text { skills in the } \\
\text { use of } \\
\text { information } \\
\text { technology as } \\
\text { a means of } \\
\text { solving } \\
\text { problems of } \\
\text { professional } \\
\text { (pedagogical) } \\
\text { activities. }\end{array}$ & $\begin{array}{l}\text { the student's } \\
\text { focus on self- } \\
\text { education in the } \\
\text { application of } \\
\text { modern } \\
\text { information } \\
\text { technologies, } \\
\text { readiness for self- } \\
\text { education, } \\
\text { awareness of its } \\
\text { need. }\end{array}$ & $\begin{array}{l}\text { - body of knowledge } \\
\text { about the object, theory } \\
\text { and technologies for the } \\
\text { implementation of } \\
\text { information processes in } \\
\text { the amount necessary for } \\
\text { the student to solve the } \\
\text { problems of information } \\
\text { activities; } \\
\text { - knowledge of the basics } \\
\text { of discrete mathematics, } \\
\text { algebra. }\end{array}$ & $\begin{array}{l}\text { - the student's } \\
\text { ability to } \\
\text { choose } \\
\text { information } \\
\text { technology or } \\
\text { method of } \\
\text { action to solve } \\
\text { a problem } \\
\text { - the ability to } \\
\text { use the basics } \\
\text { of discrete } \\
\text { mathematics } \\
\text { and algebra } \\
\text { when working } \\
\text { with } \\
\text { information } \\
\text { technology, } \\
\text { including for } \\
\text { orientation in } \\
\text { the modern } \\
\text { information } \\
\text { space. }\end{array}$ \\
\hline
\end{tabular}

The theoretical basis for the development of an algorithm for the formation of an individual educational route was the projection of the structure of information competence on the discipline "IT in professional activity", presented in Table 1. The algorithm for the 
formation of an individual educational route for a student to master the discipline "IT in professional activity" is shown in Figure 2.

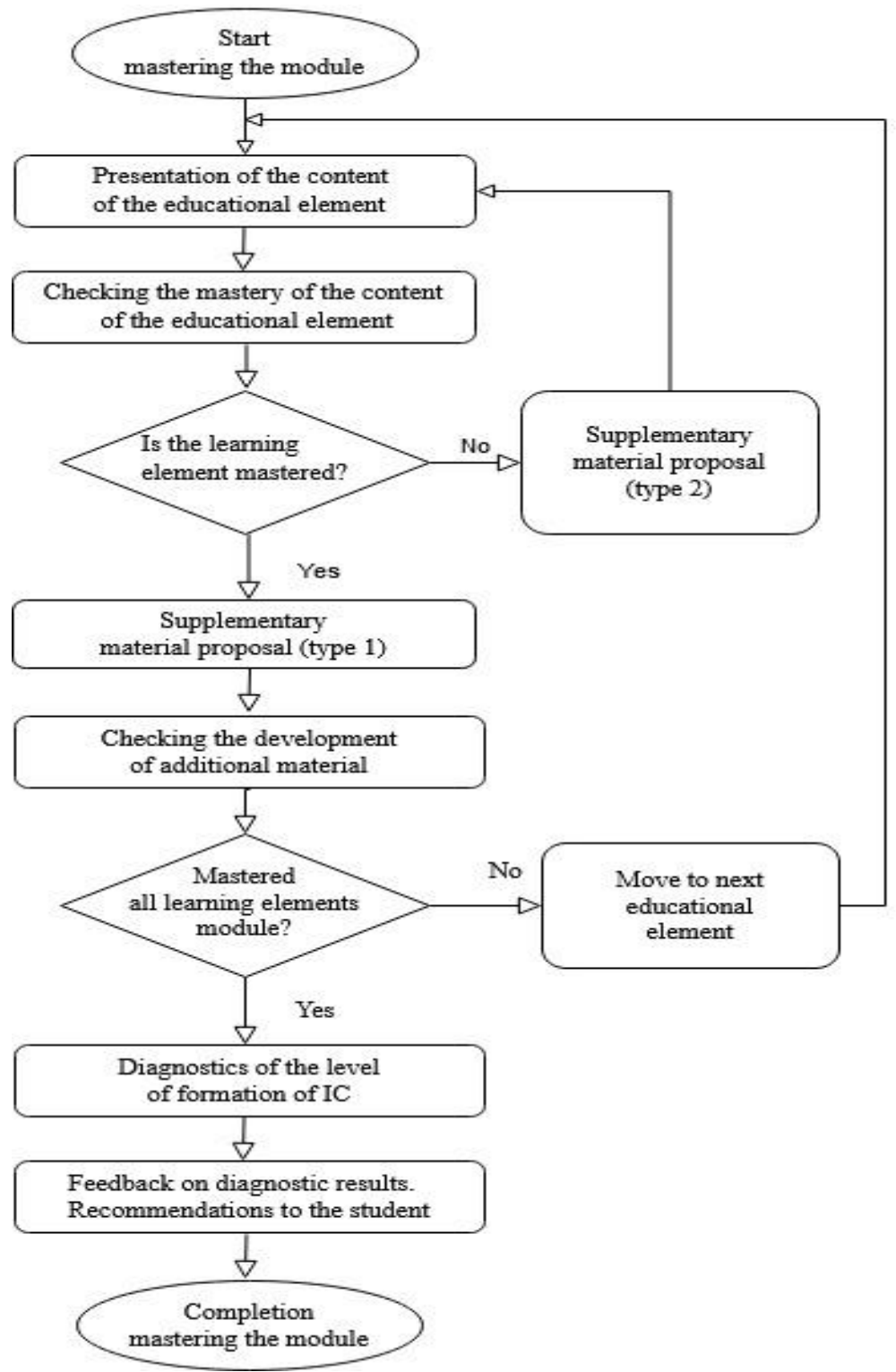

Fig. 2. Algorithm for the formation of an individual educational route of a student.

The presented pedagogical conditions were introduced into the practice of the educational process in the budgetary institution of higher education "Surgut State Pedagogical University" in the period from 2017 to 2020. The experiment involved thirdyear students of the areas of study on March 44, 05. "Pedagogical education (with two training profiles)", 44.03.01. "Pedagogical Education", bachelor's degree.

A total of 192 university students were involved in diagnostics at the entrance to the experiment. For participation in the experiment, directions and directions were selected 
with coinciding requirements for the learning outcome - competencies assigned to the discipline in basic educational programs.

To determine the dynamics of the formation of information competence of students of the pedagogical direction in the process of conducting the formative experiment, intermediate sections were performed according to all criteria (in the 2018/2019 and 2019/2020 academic years). These measurements were carried out after the completion of the first module of the discipline, in the process of studying which pedagogical conditions were created for the formation of information competence of students of the pedagogical direction.

In the final part of the control experiment (upon completion of the study of the discipline, also in the 2018/2019 and 2019/2020 academic years), we carried out a control section. Comparison of the data of the initial, intermediate and control sections made in the experimental and control groups. The average values for the criteria are shown in Table 2 and Figure 3.

Table 2. Dynamics of the level of formation of information competence of students of the pedagogical direction $(\%)$.

\begin{tabular}{|c|c|c|c|c|c|c|c|c|c|}
\hline \multirow{2}{*}{ Criterion } & \multirow{2}{*}{ Section } & \multicolumn{2}{|c|}{ Elementary } & \multicolumn{2}{|l|}{ Base } & \multicolumn{2}{|c|}{ Middle } & \multicolumn{2}{|l|}{ High } \\
\hline & & $\mathrm{CG}^{*}$ & EG & CG & EG & CG & EG & CG & EG \\
\hline \multirow{3}{*}{ Motivational } & Original & 21,2 & 21 & 30,1 & 30 & 38,9 & 38 & 9,80 & 10 \\
\hline & Intermediate & 15,4 & 11,9 & 29,1 & 26,7 & 42,2 & 38,6 & 13,4 & 22,6 \\
\hline & Control & 7,84 & 5,56 & 27,12 & 20,74 & 45,75 & 41,48 & 19,28 & 32,22 \\
\hline \multirow{3}{*}{ Cognitive } & Original & 22,4 & 19,3 & 25,9 & 27,6 & 41,2 & 42,4 & 10,6 & 10,7 \\
\hline & Intermediate & 13,3 & 10,7 & 24,5 & 24 & 45,1 & 45,8 & 17,1 & 19,6 \\
\hline & Control & 5,29 & 2,44 & 30 & 23,8 & 43,9 & 48 & 20,6 & 25,8 \\
\hline \multirow{3}{*}{$\begin{array}{l}\text { Reflexive } \\
\text { activity }\end{array}$} & Original & 20,8 & 24,7 & 28,4 & 26,1 & 33,1 & 29,4 & 17,7 & 19,7 \\
\hline & Intermediate & 12,5 & 13,6 & 24,2 & 25,8 & 38,2 & 31,9 & 25 & 28,6 \\
\hline & Control & 4,90 & 3,33 & 19,4 & 18,3 & 46,1 & 40 & 29,9 & 38,3 \\
\hline \multirow{3}{*}{$\begin{array}{l}\text { The level of } \\
\text { formation of } \\
\text { information } \\
\text { competence }\end{array}$} & Original & 21,4 & 21,9 & 28,3 & 27,7 & 37,0 & 36,1 & 13,4 & 14,4 \\
\hline & intermediate & 13,6 & 12,3 & 25,8 & 25,6 & 41,2 & 37,6 & 19,3 & 24,4 \\
\hline & Control & 5,9 & 3,8 & 24,5 & 20,5 & 45,4 & 42,5 & 24,2 & 33,2 \\
\hline
\end{tabular}

${ }^{*} \mathrm{CG}$ - control group, EG - experimental group
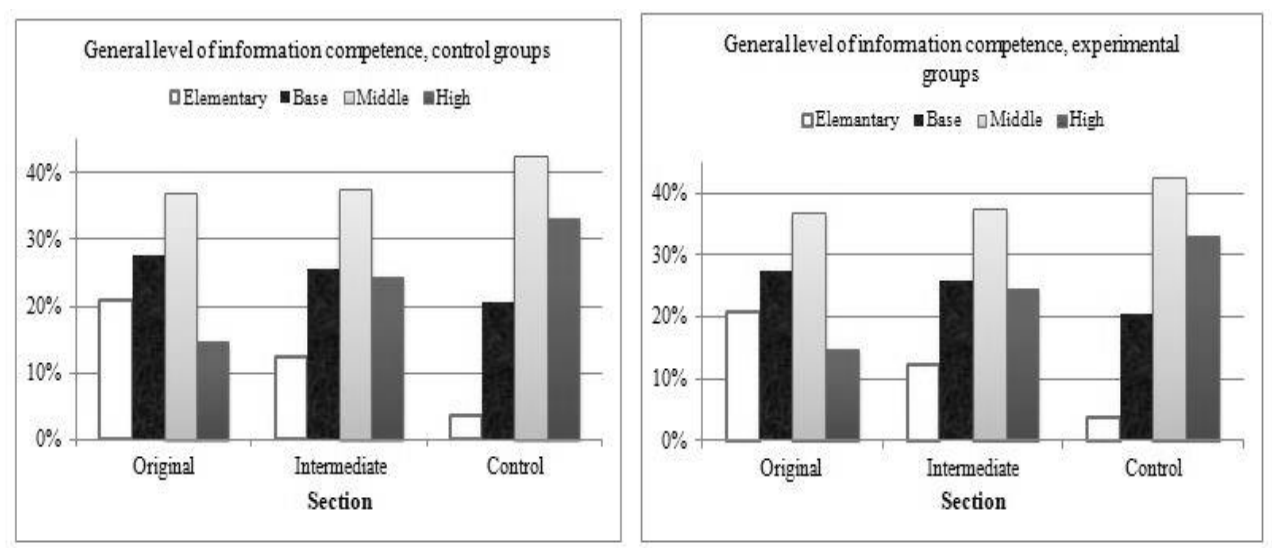

Fig. 3. Dynamics of the level of formation of information competence of students of the pedagogical direction. 
The presented data, summary and grouping of data, their graphical presentation allow us to draw the following conclusions:

- there is an increase in the general level of information competence among students of the pedagogical direction both in the control and in the experimental groups;

- positive dynamics to the experimental group is more pronounced and indicates a more significant increase in the level of information competence - for example, the proportion of students with an average and high level of information competence formation according to the control data is greater than in the experimental group.

For data processing and confirmation or refutation of the put forward statistical hypotheses, the Cramer Welch test and the $\chi 2$ test were used [22]. The values of the statistical criteria according to the data of the control section made it possible to conclude that the students of the control and experimental groups differ in the level of information competence formation with a reliability of $95 \%$. The carried out statistical processing of the research results allows us to make a well-founded conclusion that the pedagogical conditions implemented in the course of the experimental search work ensure the formation of information competence of students of the pedagogical direction at a high level.

\section{Conclusions}

The conducted research, revealed contradictions showed that the process of formation of information competence of students of pedagogical direction is relevant and insufficiently researched. The results of the study allow us to conclude that the development of the educational information environment of the university and the formation of information competence of students of the pedagogical direction are interdependent factors that ensure the successful professional activity of teachers in these conditions.

At the same time, the study of the problem of the formation of information competence of students of the pedagogical direction is not limited to this study. Scientific and methodological support of the organization of pedagogical conditions for the formation of information competence of students of the pedagogical direction can become a promising direction for the continuation and development of the research.

\section{References}

1. The information resource "Portal of Federal State Educational Standards of Higher Education”, Russia, access mode: http://fgosvo.ru/uploadfiles/profstandart/01.001.pdf

2. B.E. Starichenko, Professional standard and ICT competence of a teacher, Pedagogical education in Russia, 9, 6-15 (2015)

3. A.V. Khutorskoy, Key Competences. Design technology, Public education, 6, 55-61 (2003)

4. B.E. Starichenko, On the formation of general professional ICT competencies of students in the areas of training "Pedagogical education", Pedagogical education in Russia, 6, 97-103 (2016)

5. N.P. Tabachuk, Information competence of an individual as a subject of activity, Pedagogical Review, 4, 40-44 (2017)

6. O.V. Bugrova, To the question of the definition of «information competence of the teacher», Bulletin of Orenburg State University, 5, 6-11 (2018)

7. F.D. Rasskazov, E.V. Mityushchenko, Essence, content and components of information competence of a student of pedagogical direction, Modern problems of science and education, 4, 308-312 (2017) 
8. L.V. Astakhova, The concept of information competence of a specialist: cognitive approach, Bulletin of SUSU. Series: Education. Pedagogical sciences, 6, 10-16 (2013)

9. T.A. Sarkisyan, Formation of digital literacy of the future teacher of mathematics. Konf., Petrozavodsk, p. 44 (March 26, 2020)

10. A.R. Kamaleeva, S.U. Gruzkova, N.V. SHigapova, Quality of learning material: from assessment of knowledge to determining numerical characteristics formed competencies. Modern means of learning outcomes evaluation in the conditions of implementing a competence approach, 1, 3-10 (2016)

11. A.A. Kuznecov, E.K. Henner, V.R. Imakaev, O.N. Novikova, Problems of the formation of information and communication competence of a teacher in a Russian school, Education and Science, 7, 88-96 (2010)

12. T.N. Shamalo, N.V. Alexandrova, Formation of information competence of future teachers, Education and Sciences, 6, 63-69 (2007)

13. E.V. Mityushchenko, Analysis of Russian periodic literature on separate issues of forming the information competence of students. - Konf., Surgut, p. 72 (November 30, 2018)

14. F.D. Rasskazov, E.V. Mityushchenko, Characteristics of the pedagogical conditions for the formation of information competence in future teachers, Modern higher school: an innovative aspect, 8, 52-60 (2019)

15. M.M. Kalashnikova, V.N. Kosyrev and other, Formation of a positive attitude towards educational activities among students, 185 (1983)

16. N.Ts. Badmaeva, Influence of the motivational factor on the development of mental abilities, part 1, p. 280 (Monography, Ulan-Ude: VSGTU, 2004)

17. F.D. Rasskazov, O.Yu. Muller, E.V. Mityushchenko, Methodological possibilities of modern means of information visualization for students with special educational needs, The world of science, culture, education, 4, 153-157 (2019)

18. E.V. Mityushchenko, S.A. Kurmanova, Information visualization as a method of organizing students' activities at a curatorial hour: a reference book, p. 131 (Moscow: Publishing house "Pero", 2019)

19. A.R. Kamaleeva, V.M. Nigmetzyanova, A.N. Gryaznov, System of educational information exchange between participants of educational process, 2, 23-24 (Actualscience, 2016)

20. V.A. Dalinger, Theoretical foundations of the cognitive-visual approach to teaching mathematics, p. 143 (Omsk: Publ. OmGPU, 2006)

21. V.I. Toktarova, A.V. Ivanova, Implementation of Pedagogical Innovations in the Electronic Educational Environment of the University, Mediterranean Journal of Social Sciences, 7, 179-186 (2015)

22. D.A. Novikov, Statistical methods in pedagogical research (typical cases), p. 67 (Moscow: M3-Press, 2004) 